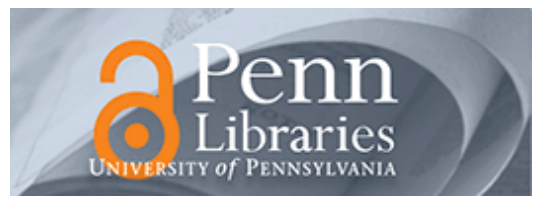

Studies in Visual Communication

Volume 9

Issue 1 Winter 1983

Article 4

1983

\title{
The Development of Standards for Scientific Films in German Ethnography
}

Martin Taureg

Recommended Citation

Taureg, M. (1983). The Development of Standards for Scientific Films in German Ethnography. 9 (1), 19-29. Retrieved from https://repository.upenn.edu/svc/vol9/iss1/4

This paper is posted at ScholarlyCommons. https://repository.upenn.edu/svc/vol9/iss1/4

For more information, please contact repository@pobox.upenn.edu. 
The Development of Standards for Scientific Films in German Ethnography 


\title{
The Development of Standards for Scientific Films in German Ethnography
}

\author{
Martin Taureg
}

By the end of the 1950s, the Institut für den Wissenschaftlichen Film (IWF) in West Germany ${ }^{1}$ had set down elaborate rules regarding the scientific purposes of ethnographic filmmaking. These rules were to guide anthropologists, who were usually unfamiliar with the medium of film, or filmmakers, who were equally little acquainted with the methods and objectives of ethnography. The rules were to ensure that scientifically satisfactory films would result from the cooperation of the IWF with ethnologists, filmmakers, and cameramen.

Neither these rules nor the related theoretical concepts have since been withdrawn or modified, though they have been subjected to some criticism in recent years. ${ }^{2}$ Even though the films produced and published by the IWF during the last fifteen years have differed to some degree from its earlier films, ${ }^{3}$ these changes have not yet led to a restatement of theory. One may assume, then, that the basic concept is still regarded as valid. At the least, the rules can be understood and examined as an expression of a particular stage of development of German ethnographic film.

In this article I will first describe this concept as well as the more practical requirements for ethnographic filmmaking that it brought about. Then I will trace some of the notions involved, and relate them to the historical context in which this particular school of ethnographic film originated. The central issues, as will be shown, had already been raised at the beginning of the century. Finally, I will consider whether the concept and standards described here are still adequate today.

Martin Taureg was educated at the Free University of Berlin (1972-1975) and the University of Hamburg (from 1975) iin ethnology (major), sociology, and American archaeology. His doctoral dissertation (nearly completed) describes the historical development and underlying theoretical concepts of ethnographic filmmaking in West Germany. These concepts - of the use of an "objective," "scientific documentation film" as an object of research - are then thoroughly criticized on the basis of a semiotic model of the process of film communication. He has worked as a part-time assistant in the Ethnographic Collection, Lübeck, and as a free-lance photographer-journalist.

Copyright (c) edition herodot Martin Taureg

Martin Taureg

$\mathrm{c} / \mathrm{O}$ Völkerkundesammlung des Museums für Kunst und

Kulturgeschichte, Düvekenstr.21, D-2400 Lübeck 1, West Germany.

(This paper will be published in N.C.R. Bogaart/H.W.E.R. Ketelaar (eds.), Methodology in Anthropological Filmmaking. Selected Proceedings of the IUAES Intercongress Symposium on Visual Anthropology. Gottingen: edition herodot, forthcoming Fall 1982.)

\section{The General Concept of the IWF}

As the central institution for scientific film in West Germany, the IWF has been of extraordinary importance to ethnographic film since the end of World War II. Nearly all West German ethnologists who have engaged in filmmaking on their field trips have cooperated with the IWF. From their work and that of their colleagues from Austria, Switzerland, and other countries during the past 30 years stems a body of more than 1500 films. The films show a remarkable conformity, which is due partly to the standards issued in 1959 and partly to the range of topics that could be covered easily by means of film (technology, dance, ritual). There have been some changes in style and scope, because, for instance, of technical improvements. ${ }^{4}$ But, on the whole, one may speak of a particular school of ethnographic filmmaking.

The basic ideas of this school were derived from a general concept of scientific film, which was formed in the first decades of this century and further developed and refined by the staff of the IWF. It has been applied to a variety of disciplines, including biology, medicine, technical sciences, and ethnology. While there may be practical reasons for a central institution to have made this sweeping application, this proce dure seems questionable on epistemological grounds, since different disciplines with different scientific problems to solve might be seen to require different methodological approaches as well.

The general concept has been described by Gotthard Wolf, the former director of the IWF, in several papers and books. According to him, scientific film is distinguished from other types of film by its purpose: in opposition to documentaries and other films popularizing science, the scientific film is "a film for science" (Wolf 1949:3). In his later publications, three categories of scientific film are discerned: the "research film," the "scientific documentation film," and the "university instructional film." Whereas the latter (like other instructional films) profits from the vivid character of motion pictures and from a didactic structure for the teaching of scientific knowledge to students, the first two types are designed to bring about new understanding in the analysis of movement. ${ }^{5}$ While the "research film," in the strictest sense of the term, is designed to solve one particular problem in the scientific study of movement, ${ }^{6}$ the "scientific documentation film" is designed to provide information on a particular type of movement of a particular object or species (Wolf 1961:16-20, 1967:9-14).

Films of this category, which was introduced by the IWF, form the basic elements of the Encyclopaedia Cinematographica (EC), a collection of films from various disciplines aimed at "systematic filmic documentation of movement" (ibid. 1961). It 
was founded by Wolf in collaboration with German and Austrian scientists in 1952 (cf. Wolf 1952, 1961, 1967; Spannaus 1955, 1961; EC 1972). Plans for such an encyclopedia had been first developed by biologists interested in the study of animal locomotion and behavior (Koenig 1966). ${ }^{7}$

The documentation film is considered as a research film in a broader sense, as a "thorough scientific description" of a particular phenomenon, which may answer a variety of questions posed by different scientists at different times (Wolf 1967:10). There are two prerequisites: The description must be as complete as is necessary and possible; and the highest possible degree of objectivity or of "content of reality," as Wolf put it, is to be achieved. ${ }^{8}$ Though the documentation film employs basically the same elements of construction as does the educational film, its formal design is subordinate to its scientific purpose. ${ }^{9}$ Sound (i.e., original sound) and color are employed only when required by the subject (music, dance, etc.); intermediate or subtitles are used sparsely, if at all. Explanation by titles or narration is generally avoided, since this is regarded as an interpretation which would prejudge that of the viewer. All additional information on the film is to be communicated by an accompanying text. ${ }^{10}$ Together only with this text, a film is regarded as a complete scientific publication (ibid.:26-31, 163-167).

"Systematic filmic documentation" in the above sense is employed whenever the processes under study are either not amenable to observation by the human eye (use of slow- or quick-motion cinematography), unique or soon to be extinguished, or to be analyzed comparatively (behavior of different species, for instance). For ethnographic purposes, the recording of (sometimes unique) events and the opportunity thereby afforded for cross-cultural comparison have been considered most important. Apart from offering data for comparative research, ethnographic film documentation is seen as especially important in regard to rapid cultural changes taking place in most parts of the world. Scientific film, functioning as a means for ethnographic salvage, is to secure documents or "research material" for future research (Wolf 1952, 1961, 1967:117; Spannaus 1955, 1961). ${ }^{11}$

Since it is regarded as impossible to make a "monographic" — but not superficial-film on the life of a particular species or ethnic group (or on all properties of a given technical matter), the documentation films are made according to the principle of the "smallest thematic unit." These units should correspond to the precise answers an encyclopedia is to offer. They should be short enough to allow easy handling and free comparison to other units, but should be full enough to guarantee a sufficiently complete and detailed description of the phenomenon in question (Wolf 1967:23-25, 29-31).
The first films published in the Encyclopaedia Cinematographica were biological ones. But, since 1957, most of the ethnographic films have also been published by the IWF as documentation films for the EC. The films in this collection are arranged by two criteria: species and type of movement (or behavior), in the case of biological films, and ethnic group and type of activity in the case of ethnographic films (for example: "Suya [Brasil, Upper Xingú]_Making of an arrow"). The structure of the encyclopedia thus permits the comparison of a particular activity across several ethnic groups or the study of several activities of one particular group_as long as the corresponding films exist (ibid.). ${ }^{12}$

From the general concept of scientific film as described here, two central ideas may be isolated. The first is the notion that, by means of cinematography or film, it becomes possible to "fix" a movement, i.e., to take or cut out a part of reality and store it on film. Thus, film becomes a kind of "movement preserve" or "permanent preparation of movement," 13 ready for multiple future reproduction and scientific analysis. The researcher does not work with but rather on the film, which serves as a substitute for reality. Wolf once referred to it as "a kind of second reality" (1961:17). Film is considered less as a method than as an object of research, as terms like "research material" (Spannaus 1955:90) suggest. ${ }^{14}$ In many respects, it is regarded as more easily researched than reality itself. By this approach, an experimental situation (otherwise unknown in ethnological field research) is introduced, where the ethnologist may examine the same complex and non-persistent movement over and over, in full detail, and with interruptions and repetitions possible at every instant.

Closely related to this first idea is the notion that a film must "contain" as much reality as possible to be scientifically valid. The demand for a "content of reality" as large as possible seems indeed logical - and better suited than that for objectivity - when considered within this approach. For if one is convinced that film may reflect or substitute for reality (or parts of it) in regard to research purposes, one has to take care that as much reality as possible is "preserved" on film and remains unchanged during the stages of filmmaking, processing, editing, etc. As far as feasible, Wolf demands, the scientific filmmaker should avoid all possible distortions of reality, up to the final screening and viewing of the film (1967:171 et seq.). Though Wolf acknowledges the subjective influence of the filmmaker (in the angle and duration of the shots, lighting, editing, etc.), he is convinced that these "subjective traits" can be controlled and minimized or extinguished, if one is aware of them (but cf Schlesier 1972; Koloss 1973; Dauer 1980; Taureg, in preparation). 


\section{Rules for Ethnographic Filmmaking}

From the application of this general model of scientific film to ethnology, as well as from the critical examination of earlier films, rules for correct ethnographic filmmaking were developed and published in 1959. They are mainly the work of Günther Spannaus, an ethnologist and the first head of the ethnological department at the IWF. ${ }^{15}$ According to him, the weakness of the earlier films - apart from technical shortcomings - is their "medley-type character."

Incomplete sections of film, most of them shot by a stationary camera without the use of panning, long shots, close-ups, etc. were joined together only with the aid of the author's explanations. The then-existing technical difficulties of field cinematography (especially in tropical climates), the absence of any but the most basic filmic competence on the part of the ethnologists, and the lack of facilities for training and exchange of information and experience were held to be responsible for the poor quality of ethnographic filmmaking in Germany (Spannaus 1955, 1961; see also Dauer 1980:65 et seq.).

The "Rules for Documentation in Ethnology and Folklore through the Film" that were issued by the IWF in 1959 to ensure better results from future filmmaking begin with the statement that "film is a sequence of moving images: the scientific film generally is a permanent visual record of phenomena" (IWF 1959:238). Then examples are given of activities that may be "preserved on film, and reproduced at any time for analysis and comparison with similar phenomena from other cultures" (manufacturing techniques, hunting, fishing, gathering, farming) and of "processes in which the sound is an integral part of the visual representation of movement" (dance, manufacturing and playing of musical instruments). The rules go on to state the following requirements:

1. Often, it will not be possible to record the phenomena in question entirely, since they may last for several hours or even weeks. For scientific purposes, it is regarded as sufficient and desirable "to film 'representative' extracts," thus enabling the viewer to reconstruct the whole process. Actions repeated during that process will be filmed only a few times, whereas singular and important stages have to be recorded in their entirety (ibid.; see note 3, below).

2. The "theoretical requirements for representative sequences," the need for "a good visual introduction," and the need for clear reproduction of complex processes determine the camera angle and field of view. To introduce and to show the background, general and panning shots should be employed.

Frequent changes of camera position and a certain minimal length of shots can orient the viewer spatially.
3. Spatially separated sequences should be linked visually in a direct way, rather than by fades or intermediate titles, whenever possible.

4. The "anthropological type" of the population under study is to be shown by close-ups.

5. Associated events (like religious customs that accompany a manufacturing process) should be included.

6. Although synchronous sound recording will usu ally not be at the ethnologist's disposal, he "should always take a complete tape record of the accompanying music" and film, "repeating movements which correspond to musical repetitions" (usually quite short in the dances of primitive peoples).

7. His familiarity with the stages of a given process should enable the professional ethnologist to determine in advance what should be filmed as representative (ibid.:239 et seq.).

8. Scientific accuracy can best be achieved by sound knowledge, close human contact, and language proficiency. Modifications or even falsifications of the behavior of those being filmed because of their awareness of the presence of a camera have to be watched carefully. Any alterations being made (e.g shifting manufacturing processes from shadow to light, compressing lengthy processes, etc.) must be recorded (see below) in detail (ibid.:240).

9. A detailed written record containing "all relevant facts" such as technical data, data on the group filmed, the personnel involved, etc., is required for scientific film documentation. ${ }^{16}$

10. The above rules also apply to films on social history or folklore. 


\section{Historical Origins}

These rules reflect the general concept of scientific film described above while they also make it more tangible by providing detailed practical instructions and examples. Although they were elaborated and published in this form by the staff of the IWF, they are built on a number of earlier efforts.

If one looks at the history of ethnographic film (and other related genres), it becomes clear that the German concept described above draws heavily on developments in two other fields: cinematography as a research tool in the natural sciences, and film as a teaching aid. The role of the culture history school of ethnological theory must also be taken into account, because of its emphasis on the study of "material culture." It has always been easier to film manufacturing processes than to search for the visual expressions of social and political structures. This may explain, for example, why film was used more by ethnologists from the German-speaking countries, who utilized a culture-historian approach, than by British social anthropologists.

Basic notions inherent in the concept described here, such as that film or cinematography can exactly reflect reality and then be reproduced and analyzed, may be traced back to the first period of scientific cinematography. This period was marked by the work of physiologists and biologists interested in the study of movement in humans and animals; their ideas had a strong influence on the concept of scientific film in general. $^{17}$

Lepenies, in analyzing the changes undergone by the human and natural sciences during the nineteenth century, points to the shift toward positive science and experimental orientation that was largely influenced by physiology. This new discipline was then thought to be the appropriate model for all experimental science, not only the study of nature. In building his concept of sociology, for instance, Comte explicitly referred to physiological notions. ${ }^{18}$ This general development of the sciences-Lepenies calls it "the empirical turn of nature history" (1978:32) should be kept in mind as a historical frame for the development of scientific cinematography arising from the demand for "exact" methods for the study of movement.

The notion of cinematography (or film) as an "exact" and "objective" method of recording motion was first introduced into ethnology/anthropology by Regnault, a French pathologist and physiologist with a strong interest in anthropology. His first "films" 19 between 1895 and 1900 actually had more in common with serial photography than with film. He made them with a "chronophotographe," a camera for rapid serial photography that had been developed by E. J. Marey around 1888. He later described his first "chronophotographic" or cinematographic ${ }^{20}$ records as "physiologie ethnique comparée" (1923:681). In several articles, Regnault outlined the principal arguments for the scientific use of cinematography (Regnault 1900 , 1923, 1931). He confronted sociology and ethnography with the "exact" natural sciences. According to him, the former had always subjective traits, even if most critical measures had been taken. In order to turn them into "precise sciences," "objective documents" such as "chronophotographies" were needed (Regnault 1900:422). Only these documents would allow for comparative analysis and measurement of movements and behavior.

Regnault was particularly concerned with the artifacts (these being "objective documents," too) collected in ethnographic museums, because only by means of cinematographic records could an exact description of the manufacturing and use of these artifacts be possible. ${ }^{21}$ In consequence, from 1900 on, Regnault demanded that museum collections be supplemented by archives storing the corresponding cinematographic records. ${ }^{22}$ At that time, however, his idea of establishing an inventory of principal movements could not be realized. It was not until fifty years later that a similar project came into existence with the founding of the EC.

In his writings, Regnault anticipated a number of features of cinematography that have since been recognized as beneficial to science. Unlike "reality," cinematographic records could be studied repeatedly and in every detail; they could be analyzed and measured frame by frame or assembled and compared with other records. Moreover, according to Regnault, cinematography would eliminate personal, subjective factors and introduce a laboratory-like, experimental situation (Regnault 1923).23

As there are close conceptual parallels between Regnault's plans for museum "film" archives and the encyclopedia that was later established by the IWF, it is not surprising that its staff frequently referred to Regnault (Spannaus 1961; Wolf 1967, 1975). Like Regnault, the institute has grounded its position on the paradigm of positive science and empirism. But Regnault did not see crucial differences between physical and social sciences in terms of how cinematography could be applied as a research tool. His main interest seemed to be in measuring and comparatively analyzing body movements, i.e., in physiology of movement and physical anthropology. One should be careful, therefore, in referring to Regnault as the "father of ethnographic film" (De Brigard 1975:15), because he used terms like "ethnography" and "cinema" differently than they are used today.

But, for the time, his approach was not unusual, as other scientists' remarks on the subject show. Little was written by ethnologists on film ${ }^{24}$ but, as the bor- 
derlines between disciplines were obviously not that strict, scholars from other fields that treated the scientific applications of cinematography may also be mentioned here. Polimanti, a biologist, was one of the most active of these scholars in the first decades of the century. He emphasized the value of cinematographic records for ethnography and anthropology as being more exact than verbal descriptions, as Regnault did. Field researchers could use these records as evidence of their observations. Others examining these records might reinterpret these observations or even discover new phenomena (Polimanti 1911:770). These accurate records could substitute for the unreliable reports of travelers. Comparison of a number of records could lead to the formulation of general notions and laws (Polimanti 1920:270).

At the same time, Lehmann, a physicist, attempted to determine the status of cinematography in science in general. Adding a third group to Spencer's taxonomy of man's inventions, he distinguished between those inventions that enlarged the abilities of the limbs or the senses of man and those that, in a way, substituted for certain limbs or senses. Lehmann assigned cinematography to the latter group, because he regarded the movie camera as an "almost completely accurate copy of the human eye." But he also recognized that cinematography could enlarge the human eye's abilities to study very quick or slow movements, measuring velocity and distance by frame-by-frame-analysis (Lehmann 1911:3-6).

Within a few years after cinematography had come into use, a body of theoretical notions on scientific cinematography was developed, as these examples may have shown. This is partly due to the role of physiological and physical research in the development of cinematography. With the quick expansion of the cinema industry, however, attention to scientific cinematography waned, although the field enjoyed a reputation in some biological, medical, and technical laboratories (Michaclis 1955, bibliography). This was not the case with ethnographic film, which in those days had extreme technical difficulties to overcome. That was probably why theoretical and methodological considerations were not raised for some time, even then sporadically, and why - as the disciplines were not that strictly distinguished - they relied heavily upon ideas formulated by natural scientists. Other sources were cinema reform and educational film movements.

\section{Institutionalizing Educational and Scientific Filmmaking}

Commercial cinema had been a most controversial public issue from around 1907 on. Teachers, clergymen, and academics in Germany considered the "living pictures" indecent and dangerous, especially for children. While some rejected the cinema completely, others demanded that its potential value for school, university, and popular education be developed and turned to advantage. ${ }^{25}$ From these efforts, a more or less informal movement for cinema reform

("Kinoreform") originated. Despite producing many books, articles, and resolutions, the movement had little immediate effect other than to introduce censorship and other means of protecting youth. Attempts to improve the quality of films (more serious plots, etc.) failed because of lack of cooperation of the film industry (Grunsky-Peper 1978).

After the end of World War I, these issues were again raised. During the twenties, an "educational film movement" ("Lehrfilmbewegung") was formed, mostly by teachers who promoted the development of films better suited to educational purposes. These films, they maintained, should meet the demands of the German school system, be able to overcome other teachers' prejudices against film, and thus be widely introduced into schools. However, there were practically no subsidies or other support by the government. Only a few schools could afford projectors and films. Again, the activities of the movement were largely limited to publishing in specialized journals, organizing meetings, etc. There were also technical difficulties to be overcome, until the $16-\mathrm{mm}$ safety film was finally introduced around 1930 (ibid.).

A fundamental change in this situation was brought about only when a central institution for educational films and other visual materials was established in 1934 by the Fascist government's Ministry of Education. As the National Socialists were convinced of film's great possibilities for instruction as well as propaganda, they eagerly installed a system of production and distribution of educational films, which soon covered nearly all German schools, colleges, and universities. In 1935, a university department was established at the central institute, the "Reichsstelle für den Unterrichtsfilm." Later, when its scope of activities was extended to university education and research cinematography, ${ }^{26}$ this name was changed to "Reichsanstalt für Film und Bild in Wissenschaft und Unterricht" (RWU). Its work-which the Allied forces judged to be neutral and objective, with a few exceptions ${ }^{27}$ - was continued in West Germany soon after the end of the war. The department of university and research films became an independent institute in 1956, the "Institut für den Wissenschaftlichen Film." 


\section{Lines of Conceptual Development}

If one takes into account this historical development, which I have only sketched here, it becomes clear how deeply the concept of the IWF is grounded in a tradition of scientific and educational film. In addition to the ideas of the early promoters of scientific cinematography outlined above, other principles that form part of the IWF's concept were raised by the reform and educational film movements: the "single concept film," which concentrated on only one subject and had to be short enough to be integrated into a lesson; the rejection of explaining titles and narration, which would interfere with the teacher's personal concept; and the idea that films should cover only those topics in which movements played an important role (IWF, Rule 1, above).

By the end of the twenties, the promoters of educational film had developed their own independent concept of film, opposed to the theatre films which they criticized as hasty and superficial. Educational films were to treat their subject completely and with necessary details and had to be structured pedagogically ${ }^{28}$ (Grunsky-Peper 1978; Terveen 1959).

As early as 1914, for example, Häfker, a geography teacher engaged in cinema reform, outlined the shape and possibilities of film for geography and ethnology. Besides emphasizing the authenticity and vividness of cinematography, he pointed to difficulties arising out of perceptual problems (because of quickchanging shots, etc.). To overcome these problems, the screening of a film was always to be accompanied by additional material (photographs, maps, written or spoken explanation, original or imitated sounds). Attention had to be paid to the aesthetic shaping as well. Such a combined screening he called a "Kinetographie" (Häfker 1914:15-19). According to him, the screening "of a negro dance without the accompanying music" was not scientific at all (ibid.:24). ${ }^{29}$ All these precautions and measures were designed to achieve the highest possible degree of accuracy; thus, the cinematographic record could even substitute to a certain extent for the "real" object of research (ibid.:27). ${ }^{30}$

Another reformer, Lange, demanded in 1918 that everyday folk activities be filmed for popular education. Concentrating on limited topics, these films would be designed aesthetically to create an emphatic pictorial impression. On the other hand, Lange stressed the importance of authenticity, insisting that no scenes should be arranged artificially (GrunskyPeper 1978:151).
Many similar ideas of the time were summed up and reviewed by Kalbus in his book on the history and the range of different applications of the educational film (1922). On ethnographic and geographic research films, he made some of the same points as Polimanti. Film could provide an irrefutable record of a researcher's travels; it could retain changing or disappearing phenomena for future study and comparison. But to guarantee the scientific value of these films, special attention had to be paid to achieving a "genuine documentary reproduction of reality" (ibid.: 135-140). ${ }^{31}$ Without compromising authenticity, compromises -in selection of the essential and the beautiful, for example - had to be made in order to produce an aesthetic product, too, at least for educational purposes. To supply additional, nonvisual information, Kalbus considered texts accompanying a film to be indispensable (ibid.:143-145).

During the following years, the concept of educational or instructional film was further developed, focusing more and more on the role of film in regular classroom lessons. The basic principles of the central distribution system put into practice in 1934 by the Nazi government had already been developed around 1931. International conferences on educational film in 1927 and 1931 helped to define more precisely terms like educational film and research film (Grunsky-Peper 1978:95-126).

Although some professional ethnologists during this period took cameras into the field, few produced noteworthy statements on the theory and methodology of ethnographic films. The only exception known to me is Krause, who, in 1928, came to the conclusion that films of foreign peoples were valuable cultural documents, offering others the opportunity to study these cultures at home and in detail that would not be possible in the field. He demanded that these films ${ }^{32}$ be made permanently available to science by the establishing of an anthropological and ethnographical film archive. The archive would store all the relevant material and make available single shots or sequences from these films for research or teaching purposes. Krause felt that the rapid decline of traditional culture made this task enormously important (Krause 1929). ${ }^{33}$

When the university department of the RWU began its work in 1935, it naturally emphasized instructional films. A survey of existing university and museum films was made; those films that were considered scientifically valuable were re-edited and published according to the RWU's standards for instructional films. ${ }^{34}$ Those considered to be unsuitable for teaching but of research interest were kept in the archive. Moreover, the term "research film" as defined by previous international conferences (Terveen 1959:170 et seq.; Grunsky-Peper 1978:97 et seq.) was divided into three categories by Schwarz, an RWU staff member, and K. Zierold (a ministry officer). The "analytical 
research film" solved a specific scientific problem in the analysis of motion. The "document film" served as demonstration or evidence. The "film with the character of a scientific publication" (completed by a written record providing necessary data) offered a new way of publishing the results of research. Ethnographic films were usually classified in the second category (Schwarz 1936:29 et seq.; Zierold 1938:266).

Zierold also dealt with the knowledge to be gained by studying film. Whereas the "real" event could never be repeated in exactly the same form or manipulated to the researcher's convenience in other ways, the film could be reproduced again and again, repeated in part or examined frame by frame with details magnified. In some situations, according to Zierold, a thorough scientific observation might be possible only in this way (Zierold 1938:272).

The IWF's concept of scientific cinematography clearly relies to a great extent on the earlier notions of natural scientists like Marey, Regnault, Polimanti, and others, and equally on the ideas formed during the development of educational film. The notion that film may be used as a substitute for the real object of research - that it is possible to retain and preserve real motion on film to be studied by other, future researchers under a variety of different (even still unknown) conditions-dates back to the beginning of the century. If film is to function as "a kind of second reality" (Wolf 1961:17), it is vital to ensure that it "contains" the greatest possible "amount" of reality. ${ }^{35}$ Thus documentary accuracy and authenticity were also emphasized by these pioneers. Promoters of educational film also stressed this issue in expressing their ideas about the formal, pedagogical design of instructional films. Unlike theatrical films, instructional films were restricted to one topic only, which was to be treated fully. Camera angles and shot length were to enhance the viewer's understanding of the subject (Caselmann 1961:18 et seq.)

The film categories of the IWF, especially that of the "documentation film," can be seen to be a blend of principles from these two sources. On the one hand, as a cinematographic record of one particular process of motion, a documentation film is to function as the object of many-sided future studies. On the other hand, it has to serve as a "thorough scientific description," as Wolf demanded (1961:17). Thus, its formal design has to take into account principles similar to those governing the instructional film, as described above.

\section{Scientific Cinematography and Culture Historicism}

We have now located the general concept of scientific film that was presented by the IWF within a par ticular historical and theoretical context. One might ask, however, why this concept, which originated largely in the natural sciences, was applied to ethnology as well. I have already tried in part to answer this question above. But it will also be useful to touch upon the role played by culture historicism ("Kulturkreislehre"), which was dominant in German and Austrian ethnology for a long time.

Generally, culture historicists may be characterized as "rigidly empirical," viewing "culture as an aggregate of objects" (Voget 1975:363). ${ }^{36}$ The comparative study of artifacts (mostly in museum collections) was a central concern of "Kulturkreislehre." A methodology of form comparison (based on the criteria of form and quantity) had been developed by Graebner and others in order to determine historical relationships and to arrange the objects under study into cultural elements, areas, and strata. Far-reaching historical reconstructions were then presented but were later criticized and rejected, on the grounds that the "methodological controls proved insufficient to justify the acceptance" of such broad reconstructions (Voget 1975:359).

This rejection seems to have led, at least in German ethnology, to a deliberately non-theoretical, self-restricted attitude of "pure description." 37 Some ethnologists tried then to escape the problem of defining precisely under what circumstances given objects could be considered the same. They argued that a careful examination of the process of their manufacture, carried out by film, would help (Spannaus 1957; Schmitz 1958). The study of these cinematographic records, moreover, according to Spannaus and others, would avoid "conceptual simplifications" produced by verbal description. A cinematographic record, on the contrary, which was regarded as an objective, "non-corruptible document," would make possible a "direct and unbiased observation" of the process in question (Spannaus 1957:254). This may explain why, even in the fifties, German ethnologists rooted in the culture-historical school still referred back to notions developed by physiologists and biologists half a century before, why they relied on issues such as accuracy, completeness, and direct recording.

Leaving aside for now the question of the importance of these ideas for the physical or physiological analysis of motion, I am convinced that the concept of scientific film and the rules for ethnographic filmmaking described here are no longer adequate for today's ethnology or cultural or social anthropology. ${ }^{38}$ 
They must be seen to be the outcome of a particular stage of development in the history of science. Nowadays, "Kulturkreis" theory seems utterly out of date. The notion of the "objective photographic record" is brought into question by developments in epistemology as well as in film theory (information theory, semiotics of film). That is why the concept of the scientific ethnographic film has to be redefined and new standards have to be developed for the production and judgment of ethnographic films.

I cannot discuss here how this actually could be achieved. One very promising approach for future work, begun about ten years ago, is an integration of relevant ethnological and film theory (Ruby 1971; Worth 1972:12). Since then, there have been some other contributions that could serve as a starting point for further discussion (Ruby 1975; Feld/Williams 1975). Ethnographic film, like any other film genre, must be understood as a medium by which information (which is ethnologically relevant) is communicated, within a semiotic process. That is, information is coded into signs by the filmmaker and decoded by the viewer. From what we do know about the complex processes of coding and decoding, of generating and perceiving visual information, it becomes clear that objectivity in the above sense cannot be achieved at all. Only a relative objectivity is conceivable, within the limits of which all critical and reflexive social science research must be conscious.

Though the technical process of cinematography may store information mechanically and, within given limits, accurately, this is not what we "see" when we view a film. Visual perception and information processing must be regarded as generally active and selective processes; a filmic epistemology must take this into account.

\section{Notes}

An earlier version of this article was published in L'Immagine dell 'Uomo, Rivista del Festival dei Popoli, Gennaio-Aprile 1982, No. 1. pp. 131-149 (Florence: Le Monnier, 1982). It was based on a paper presented at the Symposium on Visual Anthropology, IUAFSIntercongress, Amsterdam, April 23-25, 1981. The material for this paper was mostly collected in the course of my dissertation research on the history and theory of ethnographic film in Germany. For help in locating some of the literature and for useful advice I am indebted to D. Kleindienst-Andrée (IWF) and A. M. Dauer (Graz). The views expressed in this paper and eventual errors are my responsibility, however. All citations from German and French sources are my translation.

1 The address of the IWF is Nonnenstieg 72, D-3400 Göttingen, West Germany.

2 In his 1967 book on the Encyclopaedia Cinematographica, Wolf reproduced the rules without any alterations. For modification or critique of the IWF's concept see Schlesier 1972, Koloss 1973, and Dauer 1980.

3 The introductory panning (IWF Rule 4, 1959:239) was by and by replaced by other (syntagmatic) forms more suited to describe the setting (Dauer 1980:24 et seq.). From the mid-sixties on, the principle of filming "representative extracts" (IWF Rule 3, 1959:238) was given up in part. Under Dauer's influence, some ethnologists and filmmakers began covering events using a more developmental approach. By giving special attention to the transition between the end of one component action and the beginning of the next, this method ("intermittent method," or "AVE-Prinzip"; Schlesier 1972:7 and Dauer 1980:89-116) aims at presenting processes genetically. Thus their inherent logic can be understood far better than by simply "extracting" more or less random pieces of action.

4 Since 1964, special expeditions have been carried out for synchronous sound recording with the technical staff provided by the IWF. This has allowed the production of films of a higher, more professional quality. There are some disadvantages, however, such as the high cost and the disturbance caused by large camera crews (Koloss 1973).

5 For scientific purposes, three possibilities offered by cinematography were considered valuable: the recording ("fixation") of dynamic processes, the slow- or quick-motion recording ("transformation of time"), and the comparative study of dynamic processes (Wolf 1961:21)

6 This definition of research film proper is narrower than that of Michaelis (1955:1): "A research film results from the application of cinematography to the systematic search for new knowledge in the sciences" (emphasis omitted).

7 The development of the EC, as well as of ethnographic film in Germany, is treated more fully in my dissertation (in preparation).

8 I have tried to give an adequate translation of the German term "Wirklichkeitsgehalt" coined by Wolf. According to Dauer (1980:8), this is a broader term than "objectivity," as it refers to all stages of the filmmaking and viewing process (cf. Wolf 1967:171 et seq.).

9 E.g., in the duration of shots, scientific structuring, and treatment. Portions of it, however, may sometimes be used for the assembly of educational films.

10 This text must conform to similar strict requirements. The attempt to avoid influencing the viewer's interpretation was rightly criticized by Koloss (1973) as being impossible.

11 In 1957, Wolf (who stressed this point very often) reported some German ethnologists to be afraid that in twenty years their discipline would turn into some kind of archaeology (1957:482).

$12 \mathrm{Cf}$. other publications by Wolf and Spannaus. It is how r. Other almost impossible to determine the limits of such thematic units, since they depend on the particular problem to be solved; see the detailed critique by Koloss (1973) 
13 These terms ("Bewegungskonserve," "Bewegungsdauerpräparat"), which I have tried to translate, and others were frequently used by Wolf and Spannaus or considered as alternative terms for "filmic documentation of motion" (Wolf 1961:19, n. 2).

14 "Forschungswerkstoff," "Forschungsmittel," etc.; cf. Spannaus 1955:90, passim.

15 He served between 1957 and 1960. Apart from Wolf, who, although trained as an engineer, took great interest in ethnology, Spannaus was in large part responsible for the development of ethnographic film in West Germany after World War II.

16 This record is considered essential for the publication of a film by the IWF. Every film is accompanied by a printed text, giving data on the conditions of filming, a summary of the contents of the film, a short general description of the ethnic group involved, and references. This procedure, which is indeed very valuable, originated before the war, as I will discuss.

$17 \mathrm{Cf}$., for example, the work of Marey, Muybridge, and others; see De Brigard (1975) or Rhode (1978) for details of the development of film.

18 Cf. Lepenies (1978:169 et seq.) for a description of the mutual influences of physiology, pathology, and the social sciences.

19 Topics were Africans walking, climbing, sitting down, etc.; see De Brigard (1975:15 et seq.) and Michaelis (1955:193 et seq.)

20 By "cinematography" I mean, as does Michaelis (1955:1), "a series of separate images, recorded on the same continuous light-sensitive ribbon and exposed at standard intervals of time, to represent successive phases of movement; when exhibited in rapid sequence above the fusion frequency of human vision, the separate images persist long enough in the mind of the observer to reproduce the appearance of continuous motion." By "film" I mean the use of cinematographic records in such a way as to produce the notion of a continuous process. In this way, cinematographic records assembled in a certain coherent sequence may be used to present or describe actions and other processes. A film may then be regarded as a special kind of (narrative or descriptive) text (Dauer 1980:7).

21 "En analysant, en mesurant ces documents objectifs, en les comparant, en les sériant, ils [scholars from all "mental sciences"] arriveront à fixer les méthodes qui conviennent à leur science et à connaître les lois de la mentalité humaine. Le musée d'ethnographie avec ses collections d'objets, de films et de phonogrammes deviendra leur laboratoire et leur centre d'enseignement" (Regnault 1931:306; cf. 1900, 1923).

२2 Though he claimed at first that an "International Ethnographic Congress" held at Paris in 1900 had passed a corresponding resolution (the text of which he cites, 1900:422), I could not find any sound evidence for this or even for the whole congress. Wolf and Spannaus, who frequently referred to this fictitious resolution, obviously took it over from Michaelis (1955:193) who printed a not very exact translation of Regnault's text from 1900. Instead of "chronophotographic," which means something similar to serial photography, he put "film," for example.

२3 "A science exacte, il faut documents objectifs, d'où le facteur personnel disparaisse. ... Seul, le cinéma fournit en abondance des documents objectifs" (ibid.:680; cf. note 21, above)

24 There are only sparse remarks from ethnologists from the Germanspeaking area of that time. Most of these are simply reports of practical experiences. Their main use of cinematography was for ethnographic salvage and the vividness with which moving pictures could describe complex movements such as dances (Pöch 1907; Stoll 1918).
25 The so-called "natural shots" ("Naturaufnahmen") were generally considered ideal.

26 Most of the work carried out there concentrated on medicine and the technical sciences. Tolle (1961) gives a detailed description of the development of this institute; Grunsky-Peper (1978:177 et seq. 301 et seq.) critically examines its role in the Nazi state.

27 Most of the films received permission to be used again. GrunskyPeper, in an analysis of folklore films for primary and secondary ed ucation, has pointed to the implicit ideological values of these films (1978:301 et seq.)

28 Spannaus's critique of "Kulturfilme" and documentaries was grounded on similar arguments (1955:87, 94; $1961: 71$ et seq.).

29 This argument was raised again fifty years later by Fuchs (1966).

30 Here again is a close parallel to the later IWF concept. Häfker employs the term "observation of reality" ("Wirklichkeitsanschauung") (1914:27).

31 This term comes quite close to Wolf's "content of reality.

$32 \mathrm{He}$ also mentions theatrical films like Nanook of the North and Moana by Flaherty, as well as rather superficial travelogues (Krause 1929).

33 Krause was later appointed to the advisory board of the university department of the RWU

34 See, for example, Gauger (1937), Schwarz (1936), and Zierold (1938). These principles were chiefly the same as those formulated by the educational film movement during the twenties (see above).

35 The notion of a "content of reality" was thus closely linked from the start to the principles of scientific cinematography. This notion was criticized plausibly by Dauer (1980:16), who argued that reality could not be divided. Therefore, film could not "contain" even a part of reality, film could but give an "impression" of reality.

36 "Culture was located in tools, processes of manufacture, ideas, customs, elements of social organization, rituals, and other conventionalized components. The human environment could be brought under the scrutiny of science and studied as dispassionately as a cell under a microscope" (ibid.).

37 This attitude can even be found in Schlesier's 1972 article, though with some reservations.

38 For ethnology or cultural and social anthropology are not primarily concerned with studying or measuring human locomotion or behavior as such, but with the inquiry into the relations of man and culture. 


\section{References}

- De Brigard, Emilie

1975 The History of Ethnographic Film. In Principles of Visual Anthropology. P. Hockings, ed Pp. 13-43. The Hague: Mouton.

- Caselmann, Christian

1961 Geschichte und Probleme von Film, Bild und Ton im Unterricht. In Reichsanstalt für Film und Bild in Wissenschaft und Unterricht, Wolfgang Tolle. Pp. 1-24. Berlin.

- Dauer, Alfons M.

1980 Zur Syntagmatik des ethnographischen Dokumentationsfilms Acta Fthnologica et Linguistica 47. Wien: Stiglmayr

- Encyclopaedia Cinematographica (EC)

1972 G. Wolf, ed. Göttingen: IWF. (Brochure in German, English, French.)

- Feld, Steve, and Carroll Williams

1975 Toward a Researchable Film Language. Studies in the Anthropology of Visual Communication 2(1):25-32.

- Fuchs, Peter

1966 Völkerkundliche Tonfilm-Dokumentation. Research Film 5(5):457-461

- Gauger, Kurt

1937 Der Film im Hochschulunterricht. Film und Bild in Wissenschaft, Erziehung und Volksbildung 3(2):33-36.

- Grunsky-Peper, Konrad

1978 Deutsche Volkskunde im Film. Gesellschaftliche Leitbilder im Unterrichtsfilm des 3.Reiches. München: Minerva/Saur.

- Häfker, Hermann

1914 Kino und Erdkunde. Mönchen-Gladbach: Volksvereins-Verlag.

- Institut für den Wissenschaftlichen Film (IWF)

1959 Rules for Documentation in Ethnology and Folklore through the Film. Research Film 3(4):238 240.

- Kalbus, Oskar

1922 Der deutsche Lehrfilm in der Wissenschaft und im Unterricht. Berlin; C. Heymanns.

- Koenig, Otto

1966 Vom zoologischen Film zur Encyclopaedia Cinematographica. Research Film 5(5):435-439.

- Koloss, Hans-Joachim

1973 Der ethnologische Film als Dokumentationsmittel und Forschungsmethode. Ein Beitrag zur anthropologischen Methodik. Tribus 22:23-48.

- Krause, Fritz

1929 Zur Frage der Gründung eines völkerkundlichen und anthropologischen Filmarchivs. In Tagungsbericht der Deutschen Anthropologischen Gesellschaft. 50. Allgemeine Versammlung, Hamburg, 1.-13. August 1928. Pp. 67-70. Hamburg: Friederichsen, de Gruyter \& Co.

- Lehmann, $\mathrm{H}$.

1911 Die Kinematographie, ihre Grundlagen und ihre Anwendungen. Leipzig: B. G. Teubner.

- Lepenies, Wolf

1978 Das Ende der Naturgeschichte. Wandel kultureller Selbstverständlichkeiten in den Wissenschaften des 18. und 19. Jahrhunderts. Frankfurt/Main: Suhrkamp.

- Michaelis, Anthony R.

1955 Research Films in Biology, Anthropology, Psychology and Medicine. New York: Academic Press.

- Pöch, Rudolf

1907 Reisen in Neuguinea in den Jahren 1904-06. Zeitschrift für Ethnologie 39:382-400
- Polimanti, Oswald

1911 Der Kinematograph in der biologischen und medizinischen Wissenschaft. Naturwissenschaftliche Wochenschrift 26(49):769-774

1920 Die Anwendung der Kinematographie in den Naturwissenschaften, der Medizin und im Unterricht. In Wissenschaftliche Kinematographie einschließlich der Reihenphotographie. F. P. Liesegang, ed. Pp. 257-310. Leipzig: Ed. Liesegang.

- Regnault, Félix L.

1900 La Chronophotographie dans l'Ethnographie. Bulletins et Mémoires de la Société d'Anthropologie de Paris, Ve Série, t.1: $421-422$

1923 Films et Musées d'Ethnographie. Compte-Rendu de la Session de l'Association Française pour l'Avancement des Sciences 11:680-681.

1931 Le rôle du cinéma en ethnographie. La Nature (2866):304-306.

- Rhode, Eric

1978 A History of the Cinema From Its Origins to 1970. Harmondsworth: Penguin.

- Ruby, Jay

1971 Toward an Anthropological Cinema. Film Comment 7:35-40.

1975 Is an Ethnographic Film a Filmic Ethnography? Studies in the Anthropology of Visual Communication 2(2):104-111.

- Schlesier, Erhard

1972 Ethnologisches Filmen und ethnologische Feldforschung. Überlegungen zur theoretischen und methodischen Begründung ethnologischer Filmarbeit. Göttingen: Institut für Völkerkunde.

- Schmitz, Carl A.

1958 Das Problem der Töpferei und die Forschungsmöglichkeiten mit Hilfe des wissenschaftlichen Films. Research Film 3(1):45-51.

- Schwarz, Eugen

1936 Der wissenschaftliche Film in Forschung und Unterricht. Film und Bild in Wissenschaft, Erziehung und Volksbildung 2(2):29-34

- Spannaus, Günther

1955 Theoretische und praktische Probleme des wissenschaftlichen völkerkundlichen Films. In Von fremden Völkern und Kulturen. Beiträge zur Völkerkunde. Hans Plischke zum 65. Geburtstag gewidmet von seinen Kollegen und Freunden, Schülern und Mitarbeitern. Pp. 85-95. W. Lang, W. Nippold, G. Spannaus, eds. Düsseldorf: Droste.

1957 Vergleich ethnographischer Töpfereifilme als Beispiel für die wissenschaftliche Auswertung von enzyklopädischem Filmmaterial. Research Film 2(5):251-255

1961 Der wissenschaftliche Film als Forschungsmittel in der Völkerkunde. Entwicklung-Probleme-Zukunftsaufgaben. In Der Film im Dienste der Wissenschaft. Festschrift zur Einweihung des Neubaues für das IWF. Pp. 67-82. Göttingen: IWF.

- Stoll, Otto

1918 Die Entwicklung der Völkerkunde von ihren Anfängen bis in die Neuzeit. Mitteilungen der GeographischEthnographischen Gesellschaft Zürich 18:1-128.

- Terveen, Fritz

1959 Dokumente zur Geschichte der Schulfilmbewegung in Deutschland. Emsdetten: Lechte.

- Tolle, Wolfgang

1961 Reichsanstalt für Film und Bild in Wissenschaft und Unterricht. Berlin.

- Voget, Fred W.

1975 A History of Ethnology. New York: Holt, Rinehart and Winston. 
The Development of Standards for Scientific Films in German Ethnography

29

Wolf, Gotthard

1949

1952

1957

1961

Der wissenschaftliche Film. Sonderdruck. Göttingen: IWF.

Die wissenschaftliche Film-Enzyklopädie. Sonderdruck. Göttingen: IWF.

Der wissenschaftliche Film. Methoden-ProblemeAufgaben. Die Naturwissenschaften 44(18):477-482.

Zur systematischen filmischen Bewegungsdokumentation. In Der Film im Dienste der Wissenschaft. Festschrift zur Einweihung des Neubaues für das IWF. Pp. 16-40. Göttingen: IWF.

1967 Der wissenschaftliche Dokumentationsfilm und die Encyclopaedia Cinematographica. München: J. A. Barth.

Der wissenschaftliche Film in der Bundesrepublik Deutschland. Bonn-Bad Godesberg: Inter Nationes.

1975

Worth, Sol

1972 Toward the Development of a Semiotic of Ethnographic Film. PIEF Newsletter 3(3):8-12.

Zierold, Kurt

1938 Wesen und Werden des Unterrichtsfilms in Deutschland. Film und Bild in Wissenschaft, Erziehung und Volksbildung 4(10):265-272, 4(11):293-300. 